\title{
The Very Foundation, Inauguration and Expanse of Sufism: A Historical Study
}

\section{Dr. Abdul Zahoor Khan}

Ph.D., Head, Department of History \& Pakistan Studies, Faculty of Social Sciences, Faculty Block\#l, First Floor, New Campus Sector\#H-10, International Islamic University, Islamabad-Pakistan; Email: dr.zahoorkhan@iiu.edu.pk; dr.zahoor2008@gmail.com

\section{Muhammad Tanveer Jamal Chishti}

Ph.D. Scholar-History, Department of History \&Pakistan Studies, Faculty of Social Sciences, Faculty Block\#l, First Floor New Campus, Sector\#H-10, International Islamic University, Islamabad-Pakistan; Email: mtanvirjamal@gmail.com

\section{Doi:10.5901/mjss.2015.v6n5s1p382}

\begin{abstract}
Sufism has been one of the key sources to disseminate the esoteric aspects of the message of Islam throughout the world. The Sufis of Islam claim to present the real and original picture of Islam especially emphasizing the purity of heart and inner-self. To realize this objective they resort to various practices including meditation, love with fellow beings and service for mankind. The present article tries to explore the origin of Sufism, its gradual evolution and culmination. It also seeks to shed light on the characteristics of the Sufis of the different periods or generations as well as their ideas and approaches. Moreover, it discusses the contributions of the different Sufi Shaykhs as well as Sufi orders or Silsilahs, Qadiriyya, Suhrwardiyya, Naqshbandiyya, Kubraviyya and particularly the Chishtiyya.
\end{abstract}

Keywords: Sufism, Qadiriyya, Chishtiyya, Suhrwardiyya, Kubraviyya-Shattariyya, Naqshbandiyya, Tasawwuf.

\section{Introduction}

Sufism or Tasawwuf is the soul of religion. The concept of Tasawwuf has existed in almost every religion. There is a much debate and many differences of opinion as to the origin of the word "Sufi". However, the authentic are the theory of Ashab-e-Sufah, woolen clothes and the Suf. In Seha Sitta, (six famous books of tradition) the word Sufi is not found at all, and Hazrat Shahab-ud-Din Suhrwardi (d.1234) in his book Awarif ul Ma'ruf, maintains that the word Sufi only appeared some two hundred years after the death of Hazrat Muhammad (P.B.U.H.) (d.632).

The first phase of Sufism was begun just after the downfall of the pious caliphate in $661 \mathrm{AD}$ to $850 \mathrm{AD}$. It was also known as the period of Tabi'un (the followers of the companions of Holy Prophet, P.B.U.H.), and Taba-Tabi'un (followers of the Tabi'un). While the main characteristics of second generation of the Sufis were the establishment of four schools of figh or Islamic jurisprudence, while the Mu'atazilah school as well as the Shi'ite influence are the other important events of that period. Third generation came into being in the end of the tenth century and ended in the beginning of twelfth century. The third generation saw a good number of popular intellectual Sufis such as Al- Qushayri (d.1072), Ali Hujwiri (d.1076), al- Ghazali (d.1111) and Abu Sa'id Abu al- Khair (d.1049).

The most important period in Islamic Sufism is the twelfth century. There are many popular Sufi orders were founded in that period of time and many of them still existed. The credit goes to these order who not only revived the true spirit of Islam but also spread it from the south Asia, central Asia, middle east Asia, Africa, Spain etc. At this time the two big Sufi silsilahs, Chishtiyya and Suhrwardiyya, were in their initial stages, and they evolved during the period when the Ghourid were attempting to overcome or subdue the Indian Rajputs. The Suhrwardiyya silsilah was founded in the Subcontinent by Hazrat Baha-ud-Din Zakriya (d.1262) and Hazrat Jalal-ud-Din of Tabriz (d.1266). Both were disciples and Khulafa of Hazrat Shahab-ud-Din Suhrwardi (d.1234). The Chishtiyya silsilah, like many others, had its roots in the fourth pious caliph of Islam, Hazrat Ali (d.661), and then of that of Hassan al Basri (d.727). Chisht is a place or town situated some hundred kilometers east of Heart in Afghanistan. Hazrat Mumshad Danuri (d.911) ordered his Khalifa named Abu Ishaq Shami (d.937), to live out his life in Chisht so he and his latter Khulafa became known as Chishtis.

The founder of the Chishtiyya silsilah in the Subcontinent was Hazrat Muin-ud-Din (d.1235) popularly known as Khawaja Gharib Nawaz. He was the great Khalifa of Hazrat Usman Harooni (d.1220),had lived in his service for almost twenty years and then, along with his Shaykh, visited the shrine of Holy Prophet (P.B.U.H.) there the Holy Prophet (P.B.U.H.) spoke to him and ordered him to go to India spread the light of Islam there (Nasr, 2000, p.127). He arrived in 
India about the time the Muslim armies were defeated by Parithvi Raj. The defeated Muslim soldiers tried to convince Khawaja Sahib not to go on, but he rejected their advice and continued his journey toward Ajmer. In the event, both Muslim rule and the Chishtiyya silsilah in the Subcontinent reached on their pinnacle in the same time. Hazrat Qutb-udDin (d.1235), who was the Khalifa of Hazrat Khawaja Gharib Nawaz, was with his Shaykh when he set out on his journey to India and arrived in Ajmer. Gharib Nawaz appointed Hazrat Qutb-ud-Din Bakhtiar Kakito be his Khalifa just forty days before his death. Sultan Al-Tutamash who was the great devotee of Shaykh Qutb-ud-Din, also helped to expand his Shaykh's Sufi order. Shaykh Muin-ud-Din and Khawaja Qutb al-Din, died on the same year in 1235(some scholars argues Hazrat Muin died in 1229), so that thereafter the whole burden fell on Hazrat Baba Farid.

\section{What is Sufism?}

Mysticism (Sufism) is not a new concept in Islam; it has existed in almost every religion. The Islamic mystics are known as Sufis. There is a very hot debate over the origin of words Sufi and Sufism. It is commonly thought that the Sufi, Zahid, and Faqir are one and same thing, but this is incorrect. They are in fact totally different from each other (Suhrwardi, 2011, p.100).

The goal of Sufi is to become one with the will of Allah Almighty while the Faqir and Zahid worship in order to reach heaven. For that purpose Sufis retired from the world and go into the jungle or wilderness. The Holy Prophet (P.B.U.H.) said that "the faqirs of my Ummah (followers) will go to paradise half day before the wealthy people, and that half day is equal to five hundred years of this world" (Suhrwardi, 2011, pp.100-104). So faqirs have some identifiable desires, but the Sufis prefer Allah above everything. According to Hazrat Dhal-ul-Noon the Egyptian (b.796 A.D/d.861), "Allah preferred them (Sufis) over everything" (Suhrwardi, 2011, p.101).

Hazrat Abu UI Hussain Nuri (b.907) says that Sufism is a name of a state in which one gives up the human desires; and the Sufis are those who live free from human jealousies and have become totally disassociated from worldly desires and human wishes (Al-Hujwiri, 1976, pp.36-37). Similarly, Hazrat Abu Umar of Damascus maintained that "to shut your eyes before the world of Sufism" (Al-Hujwiri, 1976, p.91).

\section{Origin of the Word Sufi}

There are many conflicts and contradictions among the Sufis as well as among the historians concerning the origin of the word Sufi. Hazrat Muhammad (P.B.U.H.) was not only a Prophet, but also a Sufi (Rizvi, 2003, p.20). Some insist that the Holy Prophet (P.B.U.H.) lived an austere life. He spent everything upon others and saved nothing for him. The Holy Prophet (P.B.U.H.) often wore raged clothes.

\subsection{Companions of Mound (Ashab-i-Suffa)}

There were many companions of Holy Prophet (P.B.U.H.) who lived in the mosque (Masjid-i- Nabvi). They were known as Ashab-i-Suffa. These companions gave up their houses, as well as their families in order to seek religious and divine knowledge. Such companions of the Holy Prophet (P.B.U.H.) lived under the direct supervision of the Prophet of Islam (P.B.U.H.). The Ahle-i-Suffa were four hundred in number; they followed no professions, but only collected wood and dates to live on. The Ansar of Madinah helped them. In this regard, Hazrat S'ad bin Mo'az catered to almost eighty one of them. There were many important members of the Ashab-i-Suffa (Al-Hujwiri, 1976, p.81). In Khurasan they started living in caves and a wilderness known as Shagiftiya; in Syria they were known as Jo'aya (those who live without food) due to their scanty diet(Suhrwardi, 2011, pp.107-108). The author of Mirat ul Asrar also insists out that the word Sufi is derived from Ashab-i- Suffa (Chishti, 2010, p.120).

\subsection{First Phase of Sufism: 661 to 850 A.D. (The Period of Tabi'un and Taba Tabi'un)}

The Tabi'un was the students or followers of the companions of the Prophet Muhammad (P.B.U.H.), while the Taba Tabi'un in return was the followers of the Tabi'un. In the first two centuries of Hijra, two other schools, besides Sufism, appeared on the scene the Mu'tazila school of thought and Shi'ites. The Mu'tazila school came into being during the later Umayyad period (661-750 A.D) and, under the official patronage of Mamun (r.813-832) the Mu'tazilites reached their apogee. The Shi'ites,' who adopted a totally new dogma of Islam, later created constant problems for the Abbasids, and for Sunni scholars, as well as for the Sufis.

Almost all the Sufi Orders belong to the fourth pious caliph Hazrat Ali (d.661), but the Naqshbandiyya Order 
belongs to that of Hazrat Abu Bakr (d.634), the first pious caliph of Islam. According to the author of Mirat ul Asrar, one day the Holy Prophet (P.B.U.H.) became gloomy that everyone discussed Shariat with him but no one talked of spirituality or esoteric knowledge. As result, this secret would remain undiscovered and go to his grave with him. Hazrat Ali, having pondered on this complaint, then came to the Holy Prophet (P.B.U.H.) and asked to share his wisdom. The Holy Prophet (P.B.U.H.) was much amused to hear this and taught him all the divine secrets, saying "Ali, you are like me in wilayat (sainthood) (Chishti, 2010, pp.42)."

Hazrat Awais (d.658) was another important Sufi. He too was a contemporary of the companions of the Holy Prophet (P.B.U.H.). Indeed, The Prophet of Islam (P.B.U.H.) declared him to be his companion even though he never had visited or personally saw the Holy Prophet (P.B.U.H.) during his life. Awais lived an ascetic lifetime; he was martyred in the battle of Suffin (658 A.D) while fighting alongside of Hazrat Ali (Chishti, 2010, pp.114). This latter had four spiritual khulafa: the first was Hazrat Hassan (d.670), his elder son the second Hazrat Hussein (m.681) his younger son, the third was Hazrat Hassan al-Basri ((d.728) and the fourth Kumail bin Ziad (d.703) (Chishti, 2010, pp.48).

Aside from Hazrat Ali, Hazrat Hassan Al-Basri (d.728 A.D) taught and obtained the company of one hundred and twenty companions of the Holy Prophet (P.B.U.H.), including seventy Sahabas (those who took part in the battle of Badr) (Attar, 1966, pp.1). Another disciple of Hazrat Ali was Kumail bin Ziad (d.703/82 A.H). He had spent most of his time with Hazrat Ali, but after the latter's assassination he retired into privacy. Kumail himself was assassinated by Umayyad governor Hujjaj bin Yousaf (Chishti, 2010, pp.236). Two other important Tabi'un were Harem bin Hayyan and Sa'id bin Musayyib (b.637-d.715/14-94 A.H). The former having lived for some time in the company of Awais Qarani (Al- Hujwiri, 1976, pp. 84-86).

Jami, along with Ali bin Usman as well as Farid ud Din Attar did not mention Khawaja Abdel Wahad bin Zaid (d.793/177 A.H) as a Taba Tabi'un in their works. But in fact he was a very prominent Sufi. According to Amir Kurd, he was the disciple and khalifa of Hazrat Hassan al- Basri, while the author of Mirat ul Asrar mentions him as the first khalifa of Hazrat Hassan al- Basri, and at the same time he received his khalafat from Hazrat Kumail bin Ziad (Kirmani, 2012, p. 85).

Another leading Sufi in Balkh (Khurasan) was Shaqiq al-Balkhi (d.810). He is said to have consulted with almost 1,700 Sufis. Hatem the Deaf (d.852) was his disciple and Hazrat Ibrahim bin Adham was his Shaykh (Attar, 1966, pp.193194). Al Muhasibi (781/857) another very popular intellectual as well as Sufi remained popular in all the time. The leading Islamic philosopher Abu Hamid al- Ghazali (d.1111) was very impressed by al-Muhasibi, and most of his works show the latter's influence since in general; he followed the doctrine of al-Muhasibi (Smith, 1979, p.269).

Dawud al-Ta'i (d.777) was born in Kufa and won recognition as an Imam of tariqa in this period, and Habib al Ra'i became his spiritual master while he had also lived in the company of Imam Abu Hanifa. Ma'ruf al-Karkhi (d.815), the preceptor of Sari Saqti, was another leading Sufi in Baghdad.

\subsection{The Second Generation of Sufis}

Ahmad bin Hawari (d.858/246) and Ahmad bin Khazruya Balkhi (d.864/240) were popular Sufis of this period. The former was from Syria and Junaid of Baghdad therefore said that "Ahmad bin Abi "I-Hawari is the sweet basil of Syria" (AlHujwiri, 1976, p. 118). Ahmad bin Khazruya's wife, Fatima, was the daughter of the governor of Balkh, and she was considered the Rabi'a of her time. She had spent a long time in the company of Hazrat Abu Yazid of Bestam (d.876), and she told Ahmad that he was her natural spouse although Abu Yazid was her religious consort (Al- Hujwiri, 1976, p. 120). As for Ahmad Khazruya, he was a prominent Sufi of Balkh, the disciple of Hatem the deaf (d.852) (Attar, 1966, pp.227228). Abu Sa'id Ahmad bin Isa al-Kharraz (d.899/286) was native of Baghdad who wrote almost 400 books on Sufism. He spent most of his time in the company of two other great Sufis: Hazrat Dhul al-Noun Al- Misri (d.861) and Hazrat Beshr the Bare Footed (d.841) (Attar, 1966, pp.218-220). Hazrat Yahya bin Ma'az (d.871) was another leading Sufi of his time. Of him, Hazrat Huszri said "God had two Yahiyas, one a prophet and the other a saint" (Al- Hujwiri, 1976, p. 122), although he preferred wealth over poverty, because he saw poverty is dangerous to the faith.

Another prominent Sufi of this second generation, Hazrat Amr bin Usman al-Makki (d.909/297), spent a long time in Makkah. He also wrote many books and had numerous great disciples, of whom the most important was Junaid alBaghdadi.

Hazrat Junaid of Baghdad (d.910/298) was a very important mystic among the second generation. Junaid was an advocate of sober school of Sufism. He often maintained that he got this position by adopting a course of seclusion, starvation and wakefulness at night, and spent most of his time under the supervision of his Shaykh Sari Saqti.

Hazrat Abu Saleh Hamdun al-Qassar (d.885/271) was not only a very prominent Sufi, but also the founder of Qassariyya Sufi Order. He lived in Nishapur, and was considered to be head of the Malamtiyya Order (the Blamed Ones) 
(Al- Hujwiri, 1976, p. 217). There are three categories of Malamat (blame): the first for straying from path (Malamat-i-rasti-raftan); the second from a deliberate or an intentional act or sin (Malamat-i-qasd kardan), and a third for abandoning Shariat law (Malamat-i-tark kardan). In the first case, a man performed religious work cautiously and also tried to treat others well, but people were unhappy with him and accused him of being a liar, a disbeliever, a zindaqa (hypocrite),and such a man would endure all such charges (or Malamat) with ease. In the second case, a man who is most respected and popular among the people deliberately choses a path that people do not like, so that they will begin castigating (Malamat) him. But in the third case, a man does something that is absolutely prohibited by his religion, but he does so only to rid himself of the people's devotion (Al- Hujwiri, 1976, pp. 62-65). Qassar was disciple of Abu Turaband preceptor of Safyan al-Thuri (d.778) and Abdullah Bin Mubarak (d.797), (Al- Hujwiri, 1976, p. 217) he was so pious and intention self-annihilation (fana) that Junaid of Baghdad (d.910) and Sahl bin Abdullah Tastari (d.897) agreed that if there was any possibility of achieving a Prophet Hood second only to that of the Holy Prophet (P.B.U.H.), then al-Qassar was the person most capable of doing so (Jami, 2002, p. 91).

Abu Muhammad Sahl Bin Abdullah Al-Tastari (d.897/283) was born in Taster, and met with Hazrat Dhul al-Nuon al-Misri (796-861) while performing his hajj. He stayed at night and fasted, at first, for three days. Thereafter he fasted for five, then for seven, and finally broke his fast only after twenty-five days. He continued this practice for almost twenty years (Al- Qusheri, 2009, pp. 88-89). A contemporary of al-Junaid, and a disciple of Hazrat Dhul al-Nuon al-Misri (d.861) (Jami, 2002, p. 98), advised his disciples to eat as little as possible. According to al-Tastari, to eat one time a day is only done by those who are Sadiquain (the true ones), to eat twice in a day is the habit of Momenin (true Muslims), but to eat thrice a day is the practice of grazing animals. So to eat little, avoid people and worship of Allah is true Sufism (Attar, 1966, p.197). Hazrat Sahl bin Abdullah himself became the founder of Sahlis Order, another of the ten righteous Sufi sects.

\subsection{The Third Generation of Sufis.}

The third generation in Islamic Sufism arose in $10^{\text {th }}$ and $11^{\mathrm{TH}}$ centuries. Both these centuries produced a very large number of renowned Sufis who were also distinguished as scholars. In that period, the important thing was the blind following of the jurisprudence (figh) that developed by four Imams in the second generation (Imam Abu Hanifa d.766, Imam Malik d.795, Imam Shafi d.820, Imam Ahmad bin Hammbal d.855). The Sufis of third generation tried once again to prove that the Sufism not against the Islamic Shariah.

An important Sufi and scholar of this generation was Abu'l Qasim Abdel Karim Hawazan Al-Qusheri (b.985376/d.1072-465). He was not only a major mystic but also a great intellectual. Of his numerous books, his Risalah is considered the master piece. In this he not only gave brief biographies of eighty-two leading Sufis, but also described the basic fundamental principles of Sufism, as well as of Islam. A disciple of Abu Ali Daqaq (d.1012) and Shaykh of Abu Ali Farmadi, al- Qusheri died in 1072/465 (Jami, 2002, p. 349).

Another leading Sufi of that period was Hazrat Abu'l Hassan Ali bin Ahmad al-Khurqani (d.1032/425),who was born in Khurqan thirty nine years after the death of Hazrat Abu Yazid of Bestam. He was a farmer by profession, (Attar, 2011, p.298) just like the Prophet Adam (the first man and the Prophet) who was also a farmer (Khatir, 2003, p. 68). As for alKhurqani, Al-Qushayri has elaborated on his spiritual power and said that whenever he entered the city of Khurqan, he lost all of his eloquences and felt that he was deprived of his sainthood (Al- Hujwiri, 1976, p.163). Al-Khurqani advised his disciples that they must bury him thirty feet down in the earth because Khurgan city is located higher than Bestam, and he did not want his grave to be higher than that of Hazrat Bayazid (Attar, 2011, p. 325).

Another very significant figure was Ali bin Usman al-Jullabi al-Hujwiri (d.1076/469), and when we consider Islamic Sufism in Indian Subcontinent. Popularly known as Data Gunj Bukhash, he was a Saiyid by caste. The reason for the "Jullabi" and "Hujwiri" is that he spent some of his time in both these villages of Ghazni. His father was a native of Jullab while his mother came from Hujwir (Siddique, 1977, p.25). Ali bin Usman after completing his spiritual education moved to Lahore. Another disciple of Hazrat Hassan al-Khattali, named Shaykh Hussain Zanjani, also appointed by his Shaykh was already living there. Although Hazrat Data Sahib did not want to go there, when his Shaykh insisted he agreed. When Data Sahib reached Lahore, it was night. Then when the sun rose, he saw a funeral and on enquiring he was surprised to find that it was funeral of Hazrat Hussain Zanjani (Sijzi, 2006, p.171).

The influential Sufi teacher Hazrat Abu Sa'id Abu al-Khair was born (b. 967/ 357) in Khurasan. Although a disciple of Shaykh Abu Al-Fazl bin Hassan, he also lived for sometime in the company of Abu al-Abbas Qassab, (Jami, 2002, pp.337-338) and died the in 1049. The 'Halatu Sukhunan-i-Shaykh Abu Sa'id Abne Abi 'u Khayer' provides a primary source, on his life. It was written some hundred years after his death by his grandson. Between 1170-1200, Muhammad Ibne Munawwar, a cousin of that author and himself great-great grandson of Abu Sa'id, reworked this book (with some 
additions) as the Asraru'l Tawhid fi Maqamati'l Shaykh Abi Sa'id (Nicholson, 1983, pp.1-2).

Along with Abu Yazid (d.876), Ibrahim bin Adham (d.782), al Hallaj (d.921), Shaqiq-al-Balkhi (d.810), and Abu alHassan al-Khurqani (d.1032), Abu Sa'id is considered to be one of the greatest Sufis in Khurasan. Although he did not found a Sufi Order, he remained very popular among both his contemporaries and among the followers of latter Sufi orders. Shaykh Abu Sa'id, due to his constant meditation and contemplation achieved spiritual authority. Having said this that Kaba itself sees him many time a day (Schimmel, 1975, p.222).

\section{The Chishti Preceptors}

The Chishtiyya Sufi Order had a strong link with the leading Sufi Hazrat Mumshad Danuri (d. 911/299) (Al-Qusheri, 2009, p.122). The disciple of Hazrat Hubayrah al-Basri (d. 900/287), he had received his khalafat from Hazrat Ma'ruf al-Karkhi (d.815) and was known Danuri because he born in Danur (Rahim, 1979, p.77). In Mirat-ul-Asrar, the author mentions him as the disciple of Hazrat Junaid of Baghdad (d.910), and as being a contemporary of Hazrat Ruwaym and Hazrat Abu alHassan al-Nuri (d.907) (Chishti, 2010, p.349). He was very fond of the Sama and when people asked the reason, he told them that since the Holy Prophet (P.B.U.H.), Hazrat Ali, and all of the Aulia Allah had declared the Sama godly and acceptable, he saw no reason not enjoy it (Rahim, 1979, pp.80-81).

Most famous and prominent among the khulafa of Hazrat Mumshad were Hazrat Abu Ishaq Shami (d. 937/325), Shaykh Abu Amar, and Shaykh Ahmad Aswad Danuri (Rahim, 1979, p.82). He once said that paradise and its full pleasures had been revealed to him for almost forty years, but that he could not give any importance to them (Jami, 2002, p.125). Khawaja Mumshad succeeded Hazrat Abu Ishaq Shami, whose disciples were known as the Chishti.

There are two places named Chisht, one in Khurasan, near Herat, and the other in Pakistan near, Multan (Akram, 2004, p.271). A Tehsil (sub-district) is named Chishtiyya Mandi, in the Pakistani district Bahawalnagar, because two prominent Chishti Shaykhs, Taj ud Din Sarwar, and Noor Muhammad Moharwi are buried there.

The Chishti Shaykhs sought to avoid relations with any king or sultan. They also demanded that their disciples abide by this prohibition in all conditions. So when the sultan came to meet him for a second time, Hazrat Abu Ishaq started weeping. When his disciples asked the cause, he told them that he did not know what sin he had committed to make the sultan continually call on him (Akram, 2004, p.86).

Abu Ishaq Chishti (d.937/325) succeeded Shaykh Abu Ahmad Chishti (d.966/355). He was born the son of Sultan Farstana and was a Sayid by caste. His father was the sultan of his state of Chisht, yet Abu Ahmad gave up the worldly life to become a disciple of Hazrat Abu Ishaq. The later appointed his paternal aunt to look after him and, even before his birth that her sister-in-law had given birth to a boy who latter was appointed a Qutb or Ghous (the higher rank in sainthood). When the young Ahmad grew up, he joined the company of Abu Ishaq and even when his father ordered his soldiers to bring his son back, Ahmad refused to return home (Jami, 2002, p.359).

Meanwhile, Abu Ahmad Chishti had nominated his son Abu Muhammad Chishti (d. 1020/411) to be his khalifa in Chisht. Some authors [Mawlana Jami, Dara Shakoh and Allah Diyya] have argued that he helped Sultan Mahmud of Ghazna when he attacked Somnath, (Shakoh, 1959, p.125 and Jami, 2002, p.360) but Farid ud Din Attar has insisted that it was Abu-al-Hassan al-Khurqani who helped the sultan in this campaign. Like Hazrat Baba Farid, Abu Muhammad also performed Chillah Ma'kus (40 days meditation) in a well (Kirmani, 2012, p.96 and Rahim, 1979, p.97). Abu Ahmad saw the Holy Prophet (P.B.U.H.) in his dream and was told that his son was born, and that he should adopt the Prophet's name for him. He had chosen seclusion when he was only seven years old, and his father appointed him his khalifa when he was 24 years, just a few days before his death. The apostle Khezar was also among his teachers (Rahim, 1979, pp.97-98).

Before his death in 1020, Hazrat Abu Muhammad had nominated his grandson, Abu Yousaf Chishti (d.1067/459) as his khalifa. The latter only died in 1067/459, at the age of 84 years, and he in turn had appointed his younger son, Qutb ud Din Moodud Chishti (d.1132/527), as his own khalifa and successor in Chisht. Because of the criticism of some people, a misunderstanding thus occurred between Shaykh Moodud Chishti and Shaykh-ul-Islam Ahmad Jam. In the end, the two Shaykhs resolved the matter and when Shaykh Ahmad Jam advised Shaykh Moodud to seek further education, he requested the former to instruct him. Consequently, Shaykh Ahmad Jam taught his fellow Shaykh for three days (Jami, 2002, pp.362-364).

\section{Sufism in $12^{\text {th }}$ Century}

The $12^{\text {th }}$ century has an especial importance in the history of Islamic Sufism; for the philosophy of Sufism matured during this period. Indeed, while the Sufi schools would reach their apogee in the $13^{\text {th }}$ century, they had found their initiative in 
the 12th. That century is also important because all the founders of the new orders belong to that period. It's most fascinating personalities were Imam Ghazali (d.1111), Shaykh Abdul Qadir Jillani (d.1166), Shaykh Najib ud Din Suhrwardi (d.1165), Khawaja Muin ud Din Chishti (b.1141) Abne al Arabi (d.1240), Shaykh Najm ud Din Kubra (b.1145) and Shaykh Shahab ud Din Suhrwardi (d.1234).

Abu Hamid Muhammad (d.1111), popularly known as Imam Ghazali, was a leading Islamic philosopher and intellectual, as well as a Sufi. He was born at Tus in Khurasan in 1058 and although his father died while he was a child, educated under his Shaykh, Yousaf al-Nassaj, and under Imam al-Haramyn. He became a popular theologian and was appointed as the head of Nizamiyya College in Baghdad. Along with theology, medicine and philosophy were the major subjects taught at the college, which had been founded by Nizam ul Mulk Tusi (d.1091). Al-Ghazali was only 34 years old when took charge this great institution (Smith, 1983, pp.19-20). He wrote a number of books, most important being Ihya Ilum-Id-Din, Kimiyya-i- Sa'adat, Menhaj al-Abedeen, Elm al- Kalam, Haqiqat-i-Ruhe Insani, Rodhiatul Talebeen. He was the disciple of Shaykh Abu Ali Farendi and followed the Shafi school of thought. When the Imam al-Haramyn read his book Kitab al-Manhol, he said that this sole book of al-Ghazali was more important than all of his own works (Shakoh, 1959, p.212).

Another leading Sufi was Muhy-ud-Din Muhammad bin Ali bin al- Arabi (d.1240). He propounded the doctrine of wahadat ul wajud (unity of being), which has remained very popular among the Sufis of all sects and schools. Shaykh Ahmad of Serhind (d.1624) did not reject his doctrine, but argued that wahadat-ul-shahud was superior to the wahadat-ulwajud. Fatuhat ul Mekkiyya and Fusus al Hikm were his most famous books. He was a disciple of apostle Khezar (Jami, 2002, pp.572-581).

\subsection{Qadiriyya Order}

The twelfth century saw the rise of a number new Sufi Orders in different areas of the Islamic world. Among them the most popular, especially in South Asia, were the Qadriyya, Suhrwardiyya, Chishtiyya, Kubraviyya, Naqshbandiyya, and the Shattariyya schools. The Chishti School would come in to the being only after the arrival of Shaykh Abu Ishaq (d.937) in Chisht, but in Subcontinent it was founded by Hazrat Muin-ud-Din Chishti Ajmeri (d.1236). By that time Hazrat Shaykh Abdul Qadir Jillani (d.1166) had founded Qadriyya silsillah, while the founders of the other schools had remained in his company and obtained their divine knowledge from him. Himself a descendent of Hazrat Hassan bin Ali, he was linked to the Junaidiyya Sufi Order. Born in Jiyal in 1078/471, his father was Hazrat Abu Sahle, and mother Hazrat Ume al- Khair Fatima.The village of Jiyal was located on a popular mountain named Jodi in Iraq, believed to be the mountain where the boat of the Prophet (Noah) had landed (Chishti, 2010, p.562). Abdul Qadir got the robe of Khilafat from three Shaykhs: the first was his own father, the second was Shaykh Abu Sa'id Mukhzomi, and the third was Abu al-Wafa Baghdadi. He was also took bayt on the hand of Hazrat Khezar.

When Hazrat Ghous-ul-Azam was in his teens, he lived in the company of Shaykh Hammad. Then one day he left the Shaykh and for some time went to work. The Shaykh said that one day that non-Arab (Shaykh Abdel Qadir Jillani) set his foot on the neck of all the Auliaallah (saints) (Chishti, 2010, p.533). Once he said of al-Hallaj that there was not a contemporary of al-Hallaj who guided him and if he was there at that time, he would guide al-Hallaj, and he would not be hanged or prosecuted. Instead he would help his disciples and those who loved him till the Day of Judgment (Akram, 2004, p.184). Like the Chishti Shaykhs, Hazrat Abdul Qadir refused to have any relations with the king. Whenever dervishes came to see him, he came out to his hujra (small room, or cell), shook hands with them and then returned inside without sitting with them. Yet he sat with the non-dervish, and when someone complained he replied: "I have a heartfelt relationship with dervishes: That is enough. But we deal with non-dervishes in a worldly manner because otherwise, they feel insulted" (Suhrwardi, 2011, p.540). Meshaykhs, like Imam Yafai, claimed that Hazrat Ghous al- Azam himself celebrated Giarhwin Sharif on 11 Rabi ul Sani, in the remembrance of the Holy Prophet (P.B.U.H.) every year (Urfi, 1973, p.155).

\subsection{Chishtiyya Order}

Hazrat Haji Sharif Zandni (d. 1215/612) was the Shaykh of Hazrat Usman Harooni/Harwani (d.1220) and, along with Abu Ahmad bin Moodud Chishti, the most prominent khalifa of Hazrat Moodud Chishti (d.1132). He lived in seclusion for almost forty years, during which period he ate wild fruit and the leaves of trees, while no one dared to talk about worldly matters in front of him. In addition, no one dared to offer him money (Kirmani, 2012, p.100). The very first time he came to see Hazrat Moodud Chishti, he put his head on the feet of the Shaykh, and the latter prayed for him. He also was as fond of the Sama as his ancestor Shaykhs had been (Rahim, 1979, p.125). 
Hazrat Sharif Zandni succeeded Hazrat Khawaja Usman Harooni (d. 1220/617) (Akram, 2004, pp.342-343). He was born in a village named Harwan or Haroon in Nishapur 1113/510. Hazrat Usman Harooni loved his favorite disciple Hazrat Muin-ud-Din so much that he visited India to see his favorite khalifa. Finally, he went to Makkah and spent his last years there. Among the prominent khulafa of Shaykh Usman were Hazrat Muin-ud-Din; Shaykh S'adi Lunkuchi and Shaykh Muhammad Turk (Rahim, 1979, p.135).

Hazrat khawaja Muin-ud-Din Chishti was born in Sanjar in 1141/537, and he became the favorite khalifa of Hazrat Khawaja Usman Harooni. Muin-ud-Din was popularly known as khawaja Gharib Nawaz and became a founder of Chishti Order in India (Kirmani, 2012, p.102). A member of a respectable Sayid family, his father Sayid Ghiyas ud Din, was a very pious and religious man. Muin-ud-Din Chishti left for education, and studied in Khurasan, Samarqand and Iraq. Finally, he reached Harwan/Haroon and became the disciple of Hazrat Usman Harooni (Rahim, 1979, p.137).

\subsection{Suhrwardiyya Order}

After the Chishtiyya, the Suhrwardiyya Order is the second most popular Sufi Order in India. It was founded by Hazrat Abu Najib (d.1165), the uncle of Hazrat Shahab-ud-Din Umar, (d.1234).This order further expanded under Hazrat Shahab-ud-Din. Hazrat Abu Ishaq (d.937) was a founder of Chishti School while Hazrat Muin-ud-Din also spread and popularized the Chishti silsillah. Hazrat Shahab-ud-Din Suhrwardi was the disciple of Hazrat Abu Najib, and he was a descendent of Hazrat Abu Bakr (d.634/13), the first pious caliph of Islam. He wrote numerous books but his Awarif ul Ma'ruf, which he wrote in Makkah, was by the far most important. This was taught as a syllabus for many years, and many important Sufis recommended it to their disciples. Hazrat Bahu ud Din Zakriya (d.1262), Hazrat Jalal ud Din Tabrizi (d.1266) and Hazrat Hamid ud Din Naguri (d.1244), all of whom expanded the influence of the Suhrwardiyya Order in India, were the prominent disciples of Hazrat Shahab-ud-Din Umar Suhrwardi. He enjoyed the company of Hazrat Ghousul-Azam (d.1166) and also lived in the company of apostle Khezar (Chishti, 2010, p.496).

\subsection{Kubraviyya Order}

The founder of this Order was Ahmad-bin-Umar bin Muhammad bin Abdullah-al-Janoqi, popularly known as Hazrat Najm ud Din Kubra (1145-1220). He lived in the company of many prominent Shaykhs in his search for divine knowledge. The head of Fardosiyya order, Hazrat Najm-ud-Din Kubra had received the robe of khalafat from Hazrat Abu Najib Suhrwardi as well as from Shaykh Abdel Qadir Jillani, Shaykh Umar Yasir, Kabir the Egyptian and Shaykh Ismail Qasri. The last three Shaykhs were also the disciples of Hazrat Abu Najib Suhrwardi (Chishti, 2010, p.614).

\subsection{Naqshbandiyya Order}

The Khawajgan Sufi Order, known popularly as Naqshbandiyya Order, arose up in Central Asia. Khawaja Abu Yaqub Hamdani, also known as Abu Yousaf (d.1166), was the founder of this school. He had four khulafa [Khawaja Abdullah Barqi, Hassan Andiqi, Ahmad Basoi and Khawaja Abdul Khalaq of Ghajdwan]. Abdul Khalaq (d.1179) was the most popular and the other three always followed him (Jami, 2002, p.408). Hazrat Baha ud Din Naqshbandi (b.1318/d.1388) popularized the Naqshbandiyya order. His real name was Muhammad bin Muhammad al Bukhari and he obtained his education in tariqa from Amir Kalal. But as a matter of the fact, he obtained his spiritual teaching from Abdul Khalaq Ghajdwani, the latter also living in the company of Hazrat Khezar (Jami, 2002, p.415). The Naqshbandiyya silsillah only reached India during the reign of Akbar the Great (r.1556-1605). Hazrat Baqi Billah (d.1603) was the founder of Naqshbandiyya Sufi order there, after which it latter spread and became popular thanks to his favorite disciple, Hazrat Shaykh Ahmed of Serhind (d.1624), who is commonly known as Hazrat Mujaddid Alf-I- Sani.

\subsection{Shattariyya Order}

The Shattariyya silsillah was basically a branch of Bestamiyya Sufi order in the same way as the Nizamiyya and Saberiyya were the branches of Chishtiyya School. Hazrat Abdullah Shattari (d.1415)) established this order. He was the descendent of Hazrat Shahab ud Din Suhrwardi (d.1234) and a khalifa of Hazrat Shaykh Muhammad Arif, and his order's lineage went back to Hazrat Bayazid of Bestam (d.876) (Shattari, 2005, p.161). Shaykh Abdullah himself visited Khurasan, Iraq, Azerbaijan, and in the last he lived in the company of Hazrat Ali Muwahid. After he entered in Chittor, in1143, sultan Mahmud Shah Khalji besieged its fort but could not take it. Finally, with the prayers of Abdullah Shattari, he captured the strong hold. 
The Shattariyya silsillah spread to Bengal, Malwa, Burhanpur and Gujarat, and then into Madinah, Malaya, and Indonesia (Rizvi, 2003, p.153). The Shattari made rapid progress in tariqa as compared to the Shaykhs of other orders. For other Sufis last step in wilayat (sainthood) but this is considered to be merely the first in the order of the Shattari (Shattari, 2005, p.163).

\section{Conclusion}

In finale, this investigative and analytical research paper explores that the concept of mysticism or Sufism or spirituality is not particular to Islam, but it exists in every religion. Consequently, the practices of meditation, seclusion and renunciation of this world as well as of worldly desires, can be found in every faith. In the case of Islamic Sufism, this movement began developing just after the demise of the last righteous caliph (d.661), and it remained very popular in Islamic countries for the next six to seven centuries. Then, when it began declining in all the older Islamic countries, it reached its peak in the Indian Subcontinent.

The phenomenon of Sufism came into being after the fall of pious caliphate and reached its apogee and pinnacle during the Abbasid period. The Sufis of all schools, orders or silsilahs had the same goal and ambition and that was to obtain the will of Allah Almighty. They did not perform chilhas or meditations for paradise but to get the pleasure of Allah. The Sufis of Islam have played an imperative role to convey the message of Islam that is love with the human beings, peace and harmony.

It is an absolutely out of kilter, off-centered and distorted fact that Islamic mysticism borrowed some practices like meditations or going into unworldliness from the Hinduism, Judaism, Christianity or Buddhism but the companions of Holy Prophet (P.B.U.H.) especially the Ashab-e- Suffah [companions of the mound] who became famous due to their meditation and they also adopted unworldliness soon after the demise of the Prophet of Islam (P.B.U.H.). Umayyads, especially Hajjaj bin Yousaf's (d.715) vindictiveness and later on Mu'atazilah's influence on the Abbasid, particularly Mamun al-Rashid,(r.813-832) forced the Sufis to go to the jungle and live their life in the wilderness.

There is a contradiction not only among the historians but also within Sufis on the origin of the word Sufi. Whoever, all of these rely comprehensively on three theories that are (a) concept of woolen clothes (b) concept of companions of mound and (c) the concept of Suf. The first phase of Sufism is started from 661 and ended in 850 A.D., known as the Period of Tabi'un and Taba Tabi'un. In that period a new religious school came into being known as Shi'ite and created constant problems for the Sufis as well as for the Abbasids, the then ruling dynasty. In the same time, four schools of Islamic jurisprudence (Hanafi, Maaliki, Shaafi and Hanbbali) also came into being and started to take silhouette.

Most of the Sufis who belonged to the second and the third generations were intellectuals and scholars of significance. They produced a good number of authentic works on Sufism. Besides all of these, the twelfth century is considered the culmination point of Islamic mysticism. Although the Sufi schools reached on their pinnacle in the thirteenth century but almost all of these orders were founded in the twelfth centuries. Shaykh Abdul Qadir Jillani prevalently and universally known as Hazrat Ghous al-Azam Dastagir (d.1166) was the most outstanding and stupendous personality of that epoch. All other Sufis, preceptors as well as founders, of other orders or silsilahs accepted him as their spiritual master, and even after his death not only the common people but the Sufi Shaykhs have shown great devotion to him.

\section{References}

Al-Hujwiri, A. U. (1976). Kashf al-Mahjub, tr. Reynold A. Nicholson. Lahore: Islamic Book Foundation, pp.36-37.

Attar, F. D. (1966). Muslim Saints and Mystics Episodes from the Tazkarat ul Auliya tr. A.J. Arberry. London: Routledge \& Kegan Paul, pp. 193-194.

Al-Hujwiri, A. U. (1976). Kashf al-Mahjub, tr. Reynold A. Nicholson. Lahore: Islamic Book Foundation, p.118.

Al-Hujwiri, A. U. (1976). Kashf al-Mahjub, tr. Reynold A. Nicholson. Lahore: Islamic Book Foundation, p.120.

Attar, F. D. (1966). Muslim Saints and Mystics Episodes from the Tazkarat ul Auliya tr. A.J. Arberry. London: Routledge \& Kegan Paul, pp. 227-228.

Attar, F. D. (1966). Muslim Saints and Mystics Episodes from the Tazkarat ul Auliya tr. A.J. Arberry. London: Routledge \& Kegan Paul, P. 197.

Attar, F. D. (1966). Muslim Saints and Mystics Episodes from the Tazkarat ul Auliya tr. A.J. Arberry. London: Routledge \& Kegan Paul, pp. $218-220$.

Al-Hujwiri, A. U. (1976). Kashf al-Mahjub, tr. Reynold A. Nicholson. Lahore: Islamic Book Foundation, p.122.

Al-Hujwiri, A. U. (1976). Kashf al-Mahjub, tr. Reynold A. Nicholson. Lahore: Islamic Book Foundation, pp. 84-86.

Attar, F. D. (1966). Muslim Saints and Mystics Episodes from the Tazkarat ul Auliya tr. A.J. Arberry. London: Routledge \& Kegan Paul, 
p. 1.

Al-Hujwiri, A. U. (1976). Kashf al-Mahjub, tr. Reynold A. Nicholson. Lahore: Islamic Book Foundation, p. 91.

Akram, S. M. A. (2004). Iqtibas al- Anwar, tr. Capt. Wahid Bukhash Sial. Lahore, pp. 342-343.

Al-Hujwiri, A. U. (1976). Kashf al-Mahjub, tr. Reynold A. Nicholson. Lahore: Islamic Book Foundation, pp. 62-65.

Al-Hujwiri, A. U. (1976). Kashf al-Mahjub, tr. Reynold A. Nicholson. Lahore: Islamic Book Foundation, p. 217.

Akram, S. M. A. (2004). Iqtibas al- Anwar, tr. Capt. Wahid Bukhash Sial. Lahore, 2004, p.271.

Akram, S. M. A. (2004). Iqtibas al- Anwar, tr. Capt. Wahid Bukhash Sial. Lahore, 2004. p. 86.

Al-Qusheri, A. Q. A. K. H. (2009). Risalah al-Qusheria, tr. Mufti Muhammad Sadiq Hazarwi. Lahore: Muktaba Ala Hazrat, pp.88-89.

Attar, F. D. (2011). Muslim Saints and Mystics Episodes from the Tazkarat ul Auliya tr. A.J. Arberry. Lahore: Muktaba Ala Hazrat, p. 298.

Al-Hujwiri, A. U. (1976). Kashf al-Mahjub, tr. Reynold A. Nicholson. Lahore: Islamic Book Foundation, p.163.

Attar, F. D. (2011). Muslim Saints and Mystics Episodes from the Tazkarat ul Auliya tr. A.J. Arberry. Lahore: Muktaba Ala Hazrat, p. 325.

Akram, S. M. A. (2004). Iqtibas al- Anwar, tr. Capt. Wahid Bukhash Sial. Lahore, 2004, p. 184.

Al-Qusheri, A. Q. A. K. H. (2009). Risalah al-Qusheria, tr. Mufti Muhammad Sadiq Hazarwi. Lahore: Muktaba Ala Hazrat, p.122.

Chishti, S. A. R. (2010). Mirat ul Asrar, tr. Capt. Wahid Bakhsh Sial. Lahore: Al Faisal Publishers, p.42.

Chishti, S. A. R. (2010). Mirat ul Asrar, tr. Capt. Wahid Bakhsh Sial. Lahore: Al Faisal Publishers, p.114.

Chishti, S. A. R. (2010). Mirat ul Asrar, tr. Capt. Wahid Bakhsh Sial. Lahore: Al Faisal Publishers, p.48.

Chishti, S. A. R. (2010). Mirat ul Asrar, tr. Capt. Wahid Bakhsh Sial. Lahore: Al Faisal Publishers, p.236.

Chishti, S. A. R. (2010). Mirat ul Asrar, tr. Capt. Wahid Bakhsh Sial. Lahore: Al Faisal Publishers, p.120.

Chishti, S. A. R. (2010). Mirat ul Asrar, tr. Capt. Wahid Bakhsh Sial. Lahore: Al Faisal Publishers, p.349.

Chishti, S. A. R. (2010). Mirat ul Asrar, tr. Capt. Wahid Bakhsh Sial. Lahore: Al Faisal Publishers, p.562.

Chishti, S. A. R. (2010). Mirat ul Asrar, tr. Capt. Wahid Bakhsh Sial. Lahore: Al Faisal Publishers, p.533.

Chishti, S. A. R. (2010). Mirat ul Asrar, tr. Capt. Wahid Bakhsh Sial. Lahore: Al Faisal Publishers, p.496.

Chishti, S. A. R. (2010). Mirat ul Asrar, tr. Capt. Wahid Bakhsh Sial. Lahore: Al Faisal Publishers, p.614.

Jami, A. R. (2002). Nafahat ul Uns, tr. Hafiz Sayid Ahmad Ali shah Chishti Nizami. Lahore: Shabbir Brothers, pp. $337-338$.

Jami, A. R. (2002). Nafahat ul Uns, tr. Hafiz Sayid Ahmad Ali shah Chishti Nizami. Lahore: Shabbir Brothers, p. 408.

Jami, A. R. (2002). Nafahat ul Uns, tr. Hafiz Sayid Ahmad Ali shah Chishti Nizami. Lahore: Shabbir Brothers, p. 415.

Jami, A. R. (2002). Nafahat ul Uns, tr. Hafiz Sayid Ahmad Ali shah Chishti Nizami. Lahore: Shabbir Brothers, p. 349.

Jami, A. R. (2002). Nafahat ul Uns, tr. Hafiz Sayid Ahmad Ali shah Chishti Nizami. Lahore: Shabbir Brothers, p. 91.

Jami, A. R. (2002). Nafahat ul Uns, tr. Hafiz Sayid Ahmad Ali shah Chishti Nizami. Lahore: Shabbir Brothers, p. 98.

Jami, A. R. (2002). Nafahat ul Uns, tr. Hafiz Sayid Ahmad Ali shah Chishti Nizami. Lahore: Shabbir Brothers, p.125.

Jami, A. R. (2002). Nafahat ul Uns, tr. Hafiz Sayid Ahmad Ali shah Chishti Nizami. Lahore: Shabbir Brothers, p.359.

Jami, A. R. (2002). Nafahat ul Uns, tr. Hafiz Sayid Ahmad Ali shah Chishti Nizami. Lahore: Shabbir Brothers, pp.362-364.

Jami, A. R. (2002). Nafahat ul Uns, tr. Hafiz Sayid Ahmad Ali shah Chishti Nizami. Lahore: Shabbir Brothers, pp.572-581.

Kirmani, S. M. M. (2012). Siar ul Aulia. tr. Ghulam Ahmad Bariyyan. Lahore: Mushtaq Book Corner, n.d., p.85. Also see Chishti, S. A. R. (2010). Mirat ul Asrar, tr. Capt. Wahid Bakhsh Sial. Lahore: Al Faisal Publishers, p.247.

Khathir, A. D. M. B. I. (2003). Qasus ul Ambeya, tr. Abu Soban Sayid Muhammad Asadullah Asad. Lahore: Shabbir Brothers, p. 68.

Kirmani, S. M. M. (2012). Siar ul Aulia. tr. Ghulam Ahmad Bariyyan. Lahore: Mushtaq Book Corner, n.d., p.96. Also see Rahim, S. A.

(1979). Siar ul Aqtab, tr. Muhammad Muin ud Din Dardai. Karachi: Nafees Academy, p. 97.

Kirmani, S. M. M. (2012). Siar ul Aulia. tr. Ghulam Ahmad Bariyyan. Lahore: Mushtaq Book Corner, n.d., p.102.

Kirmani, S. M. M. (2012). Siar ul Aulia. tr. Ghulam Ahmad Bariyyan. Lahore: Mushtaq Book Corner, n.d., p.100.

Nasr, S.H. (2000). Encyclopedia of Spirituality. Lahore: Suhail Academy, p.127.

Nicholson, R. A. (1983). Studies in Islamic Mysticism. Lahore: Hijra International Publishers, pp. 1-2.

Rizvi, S. A. A. (2003). A History of Sufism in India. vol. 2. New Delhi: Munshiram Manoharlal Publishers, p.153.

Rahim, A. D. S. A. (1979). Siar ul Aqtab, tr. Muhammad Muin ud Din Dardai. Karachi: Nafees Academy, p.77.

Rahim, A.D. S. A. (1979). Siar ul Aqtab, tr. Muhammad Muin ud Din Dardai. Karachi: Nafees Academy, pp.80-81.

Rahim, A.D. S. A. (1979). Siar ul Aqtab, tr. Muhammad Muin ud Din Dardai. Karachi: Nafees Academy, p. 82.

Rahim, A. D. S. A. (1979). Siar ul Aqtab, tr. Muhammad Muin ud Din Dardai. Karachi: Nafees Academy, pp.97-98.

Rizvi, S. A. A. (2003). A History of Sufism in India. vol. 1, New Delhi: Munshiram Manoharlal Publishers, p.20.

Rahim, A. D. S. A. (1979). Siar ul Aqtab, tr. Muhammad Muin ud Din Dardai. Karachi: Nafees Academy, p.125.

Rahim, A. D. S. A. (1979). Siar ul Aqtab, tr. Muhammad Muin ud Din Dardai. Karachi: Nafees Academy, p.135.

Rahim, A. D. S. A. (1979). Siar ul Aqtab, tr. Muhammad Muin ud Din Dardai. Karachi: Nafees Academy, p.137.

Suhrwardi, S. D. (2011). Awarif ul Ma'ruf,tr. Sufi Muhammad Abdul Sattar Tahir. Lahore: Shabbir Brothers, p.10.

Suhrwardi, S. D. (2011). Awarif ul Ma'ruf,tr. Sufi Muhammad Abdul Sattar Tahir. Lahore: Shabbir Brothers, pp.100-104.

Suhrwardi, S. D. (2011). Awarif ul Ma'ruf,tr. Sufi Muhammad Abdul Sattar Tahir. Lahore: Shabbir Brothers, p. 101.

Suhrwardi, S. D. (2011). Awarif ul Ma'ruf,tr. Sufi Muhammad Abdul Sattar Tahir. Lahore: Shabbir Brothers, pp. 107-108.

Smith, M. (1979). Al-Muhasibi an Early Mystic of Baghdad. Lahore: Islamic Book Foundation, n.d., p. 269.

Sijzi, A. H. (2006). Fawaid ul Fawad, tr. Khawaja Hassan Sani Nizami. Lahore: Akbar Book Sellers, p. 171.

Schimmel, A. (1975). Mystical Dimension of Islam. Chipal Hill: University of North Carolina Press, p. 222. 
Siddique, M. H. (1977). The Life and Teachings of Hazrat Data Ganj Bakhsh. Lahore: Shahzad Publishers, p. 25.

Shakoh, D. (1959). Safinatul Aulia, tr. Muhammad Ali Lutfi. Karachi: Nafees Academy, p. 125 Also see Jami, A. R. (2002). Nafahat ul Uns, tr. Hafiz Sayid Ahmad Ali shah Chishti Nizami. Lahore: Shabbir Brothers, p.360.

Smith, M. (1983). AL- Ghazali The Mystic. Lahore: Hijra International Publishers, pp.19-20.

Shakoh, D. (1959). Safinatul Aulia, tr. Muhammad Ali Lutfi. Karachi: Nafees Academy, p. 212.

Suhrwardi, S. D. (2011). Awarif ul Ma'ruf,tr. Sufi Muhammad Abdul Sattar Tahir. Lahore: Shabbir Brothers, p. 540.

Shattari, M. G. (2005). Gulzar-i-Abrar, tr. Fazl Ahmad Jiuri. Lahore: Muktaba Sultan Alamgir, p.161.

Shattari, M. G. (2005). Gulzar-i-Abrar, tr. Fazl Ahmad Jiuri. Lahore: Muktaba Sultan Alamgir, p.163.

Urfi, A. A. (1973). Ghous ul Azam Dastgir. Karachi: Gilani Publishers, p.155. 